\title{
Formation of Artificial Casein Micelles
}

\author{
Tomotada Ono, Tomomi Furuyama and Satoshi Odagiri \\ Department of Agricultural Chemistry, Iwate University, \\ Ueda, Morioka, Iwate 020, Japan \\ Received May 10, 1982
}

\begin{abstract}
The reformation of casein micelles was investigated by dialysis of simulated milk ultrafiltrate or skimmilk at a fixed temperature or by increasing the temperature from $5^{\circ} \mathrm{C}$ to $37^{\circ} \mathrm{C}$. When submicelles were dialyzed at a fixed temperature the micelles were not reformed, but were when the submicelles were dialyzed as the temperature was increased from $5^{\circ} \mathrm{C}$ to $37^{\circ} \mathrm{C}$. The salt content, casein composition and size distribution of the reformed micelles were approximately $70 \%$ of original micelles when the submicelles were dialyzed against skimmilk. The submicelles obtained from large micelles reformed into large micelles while submicelles from small micelles reformed into small micelles.
\end{abstract}

The casein micelles of bovine milk are broken down into casein submicelles on removal of calcium. ${ }^{1)}$ On the other hand, micelle-like-colloids are obtained from sodium caseinate and the halides of alkaline earth metals. ${ }^{2)}$ The formation of the colloids has been shown to be from $\alpha_{\mathrm{sl}}$-casein, $\kappa$-casein and calcium ion. ${ }^{3)}$ Schmidt and Van der Spek $^{4)}$ obtained artificial micelles from caseins by the addition of calcium. The size distribution of the micelles, however, differed from native micelles which may be explained by the presence and absence of colloidal calcium phosphate. In subsequent studies the introduction of colloidal calcium phosphate into the casein mixtures and the role of casein components in micelles were investigated. ${ }^{57)}$ In these studies artificial micelles differed from the native micelles in their stability towards ethanol, dialysis, pressure and heat. There may be two causes of this decreased stability, 1) the lack of minor caseins in the casein system and 2) the casein mixtures, without minor caseins, may differ from the native submicelles. Therefore, the objective of the present study was to investigate the formation of artificial casein micelles by the introduction of colloidal calcium phosphate to the submicelles. The submicelles were obtained by the removal of calcium phosphate from small and large casein micelles.

\section{MATERIALS AND METHODS}

Submicelle solution and casein. Small micelle-submicelles (SMS) and large micelle-submicelles (LMS) were prepared from large and small micelles of skimmilk, respectively. The large micelles were obtained by centrifugation at $15,000 \times g$ from skimmilk, and the small micelles were obtained by centrifugation at $100,000 \times g$ from the supernatant of skimmilk centrifuged at $60,000 \times g$ as described previously. ${ }^{8)}$ The micelle fractions were dispersed into $0.01 \mathrm{M}$ imidazole buffer containing $0.07 \mathrm{M} \mathrm{NaCl}$ and $0.02 \%$ $\mathrm{NaN}_{3}$ (pH 7.0) (Im-buffer). After dialysis against Imbuffer at $5^{\circ} \mathrm{C}$ for $70 \mathrm{hr}$, the suspensions were centrifuged at $100,000 \times g$ for $30 \min ^{8}{ }^{8}$ The supernatants were used for the submicelle solutions. The supernatants were further dialyzed against distilled water for $48 \mathrm{hr}$. The submicelle caseins were obtained by lyophilization of the dialyzates. Heated submicelle caseins were obtained from submicelle solutions by dialysis and lyophilization after heating at $90^{\circ} \mathrm{C}$ for $10 \mathrm{~min}$.

Simulated milk ultrafiltrate. Simulated milk ultrafiltrate (SMUF) was prepared at $5^{\circ} \mathrm{C}$ by the methods of Jenness and Koops. ${ }^{9)}$ Sodium azide $(0.02 \%)$ was added to this solution to inhibit microbial growth.

Ultrafiltrate of skimmilk. The ultrafiltrate was obtained from skimmilk containing $0.02 \% \mathrm{NaN}_{3}$ with an ultrafiltration cell (Toyo Kagaku model UHP-76) with a membranefilter UK-200 (cut-off molecular weight, 200,000) at room temperature.

Formation of casein micelles from submicelle caseins. 
Skimmilk and SMUF were stirred for $48 \mathrm{hr}$ at a fixed temperature and then filtered through Toyo Roshi No. 5 papers. The filtrates were used for formation of casein micelles. Three methods were used for the formation of casein micelles.

1. Submicelle solutions containing $3 \%$ protein were dialyzed against SMUF for $72 \mathrm{hr}$ at the temperature at which SMUF was equilibrated.

2. Submicelle caseins were dissolved in SMUF, and stirred for $72 \mathrm{hr}$ at the temperature at which SMUF was equilibrated.

3. Submicelle solutions were dialyzed against SMUF or skimmilk at $5^{\circ} \mathrm{C}$ for $72 \mathrm{hr}$ and subsequently dialyzed at $37^{\circ} \mathrm{C}$ for $72 \mathrm{hr}$.

Submicelle solutions treated as above were centrifuged at $100,000 \times g$ for $30 \mathrm{~min}$, and the precipitates, which were the reformed micelles, were dispersed in water with a Potter type homogenizer. The quantity and components of protein as well as salt contents were analyzed.

Determination of protein. After the suspension of reformed micelles was dissolved in $10 \% \mathrm{NaOH}$, the protein content was determined by the method of Gornall et $a .^{10)}$

Determination of calcium and inorganic phophorus. After the protein was removed from the suspensions of reformed micelles by the addition of an equal volume of $20 \%$ trichloroacetic acid, calcium and inorganic phosphorus were determined by atomic absorption ${ }^{11)}$ and Nakamura's

(A)

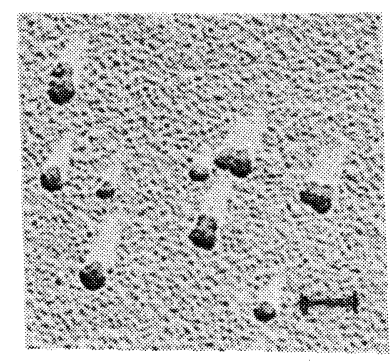

(B)

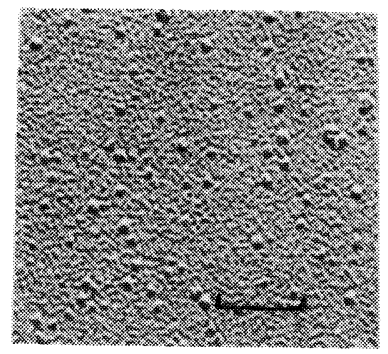

(D)

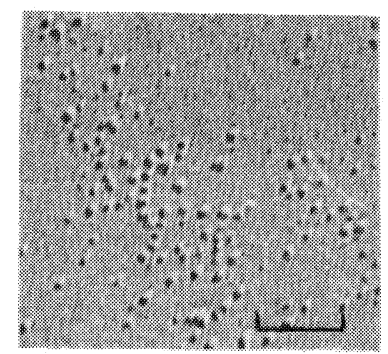

Plate I. Electron Micrographs of Large and Small Micelles before and after Dialysis against $0.01 \mathrm{~m}$ Imidazole Buffer.

Large micelles: (A) before dialysis; (B) after dialysis. Small micelles: (C) before dialysis; (D) after dialysis. shows $200 \mathrm{~nm}$ in photographs. 
homogeneous size particles (below $40 \mathrm{~nm}$ ) were observed (Plate I). It is impossible to distinguish between particles obtained from large and small micelles. These particles were the submicelles and were used for the reformation of micelles.

Dialysis of the submicelles against SMUF at a fixed temperature

When the submicelles from large micelles (LMS) were dialyzed against SMUF equilibrated at various temperatures, a precipitate was formed above $20^{\circ} \mathrm{C}$ (Fig. 1). The precipitate, however, was not formed when the heated submicelle solution was dialyzed. Similar results were obtained on dialysis against Im-buffer without calcium and phosphate. The formation of precipitates seems to be caused by unstable peptides derived on decomposition of caseins by protease. Casein micelles were not reformed when submicelles were dialyzed at a constant temperature.

Formation of casein micelles from submicelles in SMUF when the temperature was increased from $5^{\circ} \mathrm{C}$ to $37^{\circ} \mathrm{C}$

The amounts of calcium and inorganic

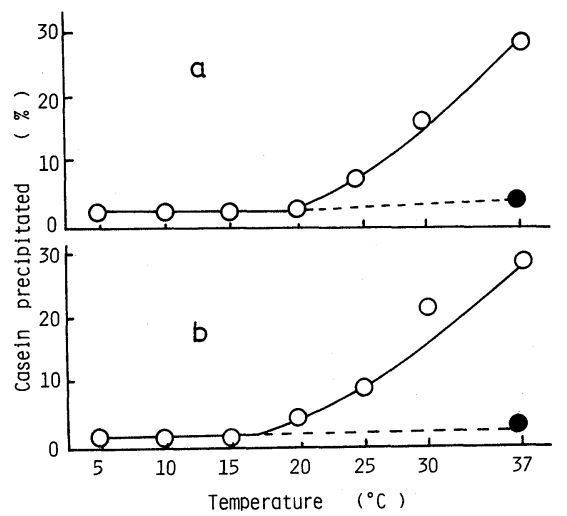

FIG. 1. The Reformation of Micelles on Dialysis of Submicelles against SMUF or Imidazole Buffer at Fixed Temperatures.

Submicelles from large micelles were dialyzed against SMUF (a) or $0.01 \mathrm{~m}$ imidazole buffer (b) for $72 \mathrm{hr}$ at 5,10 , $15,20,25,30$ and $37^{\circ} \mathrm{C}$. The precipitates were obtained from the dialyzates by centrifugation at $100,000 \times g$ for 30 min. Unheated $(O)$ and heated $(O)$ LMS were used for samples. phosphorus in SMUF varied with temperature as shown in Fig. 2. The amounts decreased with increasing temperature. Precipitates of calcium phosphate were formed due to the decreased solubility of calcium phosphate. Therefore, the introduction of calcium phosphate into submicelles was added by an increase in temperature of SMUF. After the LMS was dissolved in SMUF and stirred at $5^{\circ} \mathrm{C}$, the temperature of the solution was increased to $37^{\circ} \mathrm{C}$. A micelle-like-colloid was formed with no evident precipitate. The formation efficiency of the micelle colloid was $50 \%$, and it made no difference whether heated or unheated submicelles were used (Table I). The salt contents of the reformed micelles were $20 \mathrm{mg} \mathrm{Ca} / \mathrm{g}$ casein and $8 \mathrm{mg} \mathrm{Pi} / \mathrm{g}$ casein, corresponding to 70 and $40 \%$ of those found in

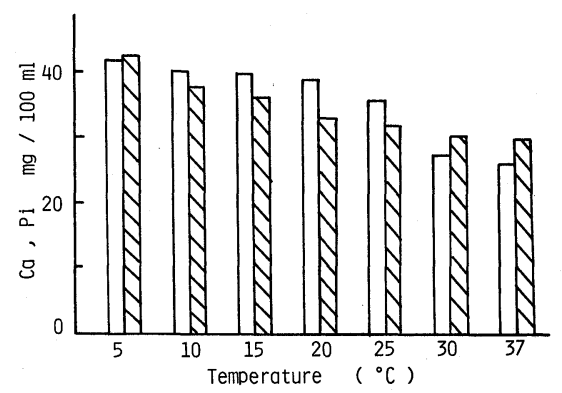

FIG. 2. The Quantities of Calcium and Inorganic Phosphorus in SMUF at Each Temperature.

$\square$, calcium; $Z \square \Delta$, inorganic phosphorus.

TABle I. The Compositions of Reformed MiCELlES FROM HEATED OR UNHEATED LMS IN SMUF ON INCREASING THE TeMPERATURE FROM $5^{\circ} \mathrm{C}$ TO $37^{\circ} \mathrm{C}$

\begin{tabular}{lccc}
\hline \multirow{2}{*}{$\begin{array}{c}\text { Proportion } \\
\text { reformed }(\%)\end{array}$} & $\begin{array}{c}\text { Native } \\
\text { micelles }\end{array}$ & \multicolumn{2}{c}{ Reformed micelles } \\
\cline { 3 - 4 } & & Heated & Unheated \\
\hline Micelles & 100 & 52 & 48 \\
Calcium* & 100 & 72 & 68 \\
& $(28)$ & $(20)$ & $(19)$ \\
Inorganic & 100 & 37 & 35 \\
phosphorus* & $(23)$ & $(8.5)$ & $(8.0)$ \\
$\alpha_{\mathrm{s}}$-Casein & 54 & 61 & 60 \\
$\beta$-Casein & 28 & 28 & 23 \\
$\kappa$-Casein fraction & 18 & 11 & 17 \\
\hline
\end{tabular}

* ( ) is $\mathrm{mg} / \mathrm{g}$ casein. 
Table II. The Compositions of Reformed Micelles from Heated LMS AND SMS ON Dialysis against SMUF OR SKIMMILK WHEN THE

TeMPERATURE WAS INCREASED FROM $5^{\circ} \mathrm{C}$ TO $37^{\circ} \mathrm{C}$

\begin{tabular}{|c|c|c|c|c|c|c|}
\hline \multirow{3}{*}{$\begin{array}{l}\text { Proportion } \\
\text { reformed \% }\end{array}$} & \multicolumn{3}{|c|}{ LMS } & \multicolumn{3}{|c|}{ SMS } \\
\hline & \multirow{2}{*}{ Native } & \multicolumn{2}{|c|}{ Reformed } & \multirow{2}{*}{ Native } & \multicolumn{2}{|c|}{ Reformed } \\
\hline & & SMUF & Skimmilk & & SMUF & Skimmilk \\
\hline Micelles & 100 & 58 & 70 & 100 & 20 & 62 \\
\hline Calcium* & $\begin{array}{l}100 \\
(28)\end{array}$ & $\begin{array}{c}71 \\
(20)\end{array}$ & $\begin{array}{c}64 \\
(18)\end{array}$ & $\begin{array}{l}100 \\
(22)\end{array}$ & $\begin{array}{c}86 \\
(19)\end{array}$ & $\begin{array}{c}77 \\
(17)\end{array}$ \\
\hline $\begin{array}{l}\text { Inorganic } \\
\text { phosphorus* }\end{array}$ & $\begin{array}{l}100 \\
(23)\end{array}$ & $\begin{array}{c}43 \\
(10)\end{array}$ & $\begin{array}{c}48 \\
(11)\end{array}$ & $\begin{array}{l}100 \\
(14)\end{array}$ & $\begin{array}{c}71 \\
(10)\end{array}$ & $\begin{array}{c}71 \\
(10)\end{array}$ \\
\hline$\alpha_{s}-$ Casein & 54 & 63 & 54 & 50 & 58 & 46 \\
\hline$\beta$-Casein & 28 & 23 & 22 & 22 & 20 & 23 \\
\hline$\kappa$-Casein fraction & 18 & 14 & 24 & 28 & 22 & 31 \\
\hline
\end{tabular}

* ( ) is $\mathrm{mg} / \mathrm{g}$ casein.

native micelles, respectively. The reformed micelles from unheated submicelles contained more $\kappa$-casein fraction (containing $\gamma$-caseins) and less $\beta$-casein than heated submicelles. This suggests that $\beta$-casein was broken by protease and migrated to the $\kappa$-casein fraction on electrophoresis.

\section{The formation of casein micelles on dialysis}

In order to increase the formation efficiency of the micelle-like-colloid, the reformation of casein micelles by dialysis against SMUF or skimmilk was examined by increasing the temperature from $5^{\circ} \mathrm{C}$ to $37^{\circ} \mathrm{C}$. Heated LMS and SMS were used for this experiment. The proportions of reformed micelles from LMS and SMS on dialysis against skimmilk were 70 and $60 \%$, respectively (Table II), and were higher than those on dissolution into SMUF. The composition of the reformed micelles on dialysis against SMUF, however, was similar to that on dissolution into SMUF. The salt contents of the reformed micelles from SMS were 71 to $86 \%$ of the contents of native micelles. The inorganic phosphorus content of the reformed micelles from LMS was lower than that of native micelles. The casein composition of the reformed micelles was similar to that of native micelles, though the $\kappa$-casein content of the reformed micelles on dialysis against skim-

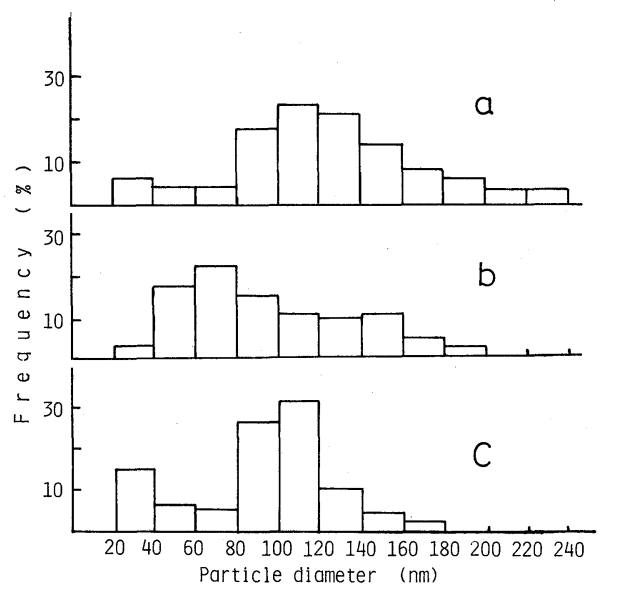

FIG. 3. The Size Distribution of Large Micelles and Reformed Micelles from LMS on Dialysis against SMUF or Skimmilk when the Temperature was Increased from 5 to $37^{\circ} \mathrm{C}$.

a, large micelles; b, reformed micelles from LMS on dialysis against SMUF; c, reformed micelles from LMS on dialysis against skimmilk.

milk was larger than that of native micelles. The size distribution of reformed micelles is shown in Figs. 3 and 4. The reformed micelles from LMS were larger than those from SMS. The size of reformed micelles on dialysis against skimmilk was larger than that obtained on dialysis against SMUF, and similar to that of native micelles. 


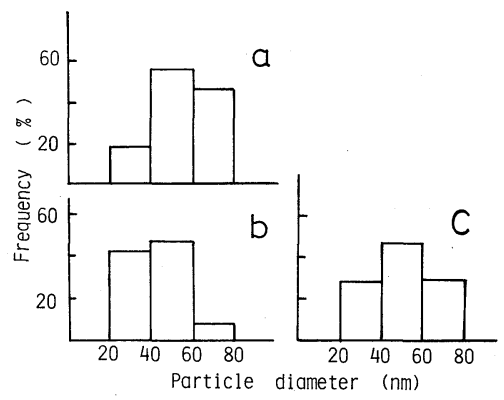

Fig. 4. The Size Distribution of Small Micelles and Reformed Micelles from SMS on Dialysis against SMUF or Skimmilk When the Temperature was Increased from 5 to $37^{\circ} \mathrm{C}$.

a, small micelles; b, reformed micelles from SMS on dialysis against SMUF; c, reformed micelles from SMS on dialysis against skimmilk.

Table III. The Clotting Time of NATIVE AND REFORMED MiCELleS

\begin{tabular}{lcr}
\hline & Native & Reformed \\
\hline Large micelles & $9 \pm 1$ & $14 \pm 1 \mathrm{~min}$ \\
Small micelles & $4 \pm 1$ & $7 \pm 1 \mathrm{~min}$ \\
\hline
\end{tabular}

\section{Measurements of clotting time}

The clotting time of native and reformed micelles was measured and is shown in Table III. The reformed micelles have a longer clotting time than the native micelles. The small micelles clotted in half the time when compared to large micelles.

\section{DISCUSSION}

When the submicelles were equilibrated in SMUF at a fixed temperature the casein micelles were not formed, however, it has been reported that colloidal phosphate-free (CPF) casein is formed. ${ }^{16)} \mathrm{CPF}$ casein contains $25 \%$ of calcium found in native micelles but little of the inorganic phosphate, and the CPF casein is not a micelle. ${ }^{16)}$ Particles formed during dialysis were below $40 \mathrm{~nm}$ (Plate), so they did not precipitate when centrifuged at $100,000 \times g$ for $30 \mathrm{~min}$ and could not be distinguished from submicelles.

The micelles formed on the addition of calcium to submicelles do not contain in- organic phosphate, and the salt composition differs from that of native ones. Schmidt and Van der Spek $^{4}$ ) reported that the micelles formed on the addition of calcium differed from native ones in the size distribution. On the other hand, it was reported that phosphate was critical in the formation of larger and more stable micelles. ${ }^{5,17,18)}$ Schmidt et al. ${ }^{5 \sim 7)}$ investigated the formation of micelles by the addition of calcium phosphate to casein and the role of the main casein components in micelles. The relation between micelles and submicelles, however, was not studied and their synthetic micelles did not contain the minor casein. The synthesized micelles differed from the native micelles in their stability towards ethanol, dialysis, pressure and heat. We attempted reformation of casein micelles not from isolated caseins or casein mixtures but from submicelles which were prepared by removal of calcium phosphate from large or small micelles.

The reformation of micelles was performed by a moderate method (dialysis and a temperature change from $5^{\circ} \mathrm{C}$ to $37^{\circ} \mathrm{C}$ ). The yield of the reformed micelles was high (60 to $70 \%$ ), and the calcium phosphate introduced into micelles was $70 \%$ that of native micelles (small micelles) (Table I). The yield of the reformed micelles on dialysis against skimmilk was higher than that on dialysis against SMUF. The transport of calcium phosphate into micellar casein is gradual when dialyzed against skimmilk, since the casein micelles in skimmilk have a buffering capacity according to the deposition and dissolution of calcium phosphate. The size distribution of the moderately reformed micelles was similar to that of native large or small micelles. Thus, the reformed micelles would seem to closely resemble the native micelles, with the exception that the clotting time of the reformed micelles was longer than that of the native micelles. The fluctuation of the time might be caused by slight differences in the salt content, casein composition and size populations between the reformed and native micelles.

Some differences in casein and salt com- 
positions were noted between small and large micelles. Choate et al. ${ }^{19)}$ reported that the caseins from large and small micelles reformed into large and small micelles, respectively. However, their results are suspect since sedimentation coefficients were obtained with a polydispered system. In our study it was clear that the LMS formed the large micelles and the SMS formed the small micelles. The reformed large and small micelles had compositions (Table II) and size distributions similar to those of the native large and small micelles (Figs. 3 and 4). The difference between SMS and LMS lies in the $\kappa$-casein content. SMS containing large quantities of $\kappa$-casein formed small micelles. Schmidt et al. ${ }^{5)}$ obtained synthetic small micelles from a casein mixture containing large quantities of $\kappa$-casein. It is postulated that $\kappa$-casein inhibits the formation of large micelles. ${ }^{20)}$ On the other hand, we ${ }^{21)}$ reported the existence of some types of submicelles. One is the $\alpha_{\mathrm{sl}}-\kappa$-casein complex which is abundant in SMS, and the others are complexes and polymers of $\alpha_{\mathrm{sl}^{-}}$and $\beta$-caseins which are found in LMS in large quantities. Micelles were formed from these submicelles by the deposition of colloidal calcium phosphate. Waugh and Noble ${ }^{3)}$ suggested that polymers of $\alpha_{\mathrm{s}}$ - and $\beta$-casein are located in the core regions of casein micelles on addition of calcium, and that $\kappa$-casein is located in the surface region of casein micelles. We hypothesize that the core of casein micelles is composed of submicelles containing little $\kappa$-casein which are linked by calcium phosphate and that the periphery of each micelle is made from submicelles containing an abundance of $\kappa$-casein. It is probable that the LMS which contains many submicelles for the micelle core forms the large micelles and the SMS containing many submicelles for the mi- celle coat forms the small micelles.

\section{REFERENCES}

1) W. K. Downey and R. F. Murphy, J. Dairy Res., 37, 47 (1970).

2) S. Adachi, J. Dairy Sci., 46, 743 (1963).

3) D. F. Waugh and R. W. Noble, Jr., J. Am. Chem. Soc., 87, 2246 (1965).

4) D. G. Schmidt and C. V. Van der Spek, Milchwissenschaft, 29, 455 (1974).

5) D. G. Schmidt, J. Koops and D. Westerbeek, Neth. Milk Dairy J., 31, 328 (1977).

6) D. G. Schmidt and J. Koops, Neth. Milk Dairy J., 31, 342 (1977).

7) D. G. Schmidt, P. Both and J. Koops, Neth. Milk Dairy J., 33, 40 (1979).

8) T. Ono, T. Furuyama and S. Odagiri, Agric. Biol. Chem., 45, 511 (1981).

9) R. Jenness and J. Koops, Neth. Milk Dairy J., 16, 153 (1962).

10) A. G. Gornall, C. S. Bardwill and M. M. David, J. Biol. Chem., 177, 751 (1949).

11) T. Ono and S. Odagiri, Jpn. J. Dairy Sci., 24, A-133 (1975).

12) M. Nakamura, Nippon Nôgeikagaku Kaishi, 24, 1 (1950).

13) A. H. Gordon, "Laboratory Techniques in Biochemistry and Molecular Biology," Vol. 1, ed. by T. S. Work and E. Work, North-Holland Publ. Co., Amsterdam, 1969, p. 50.

14) R. J. Carroll, M. P. Tompson and G. C. Mutting, J. Dairy Sci., 51, 1903 (1969).

15) T. Ono, T. D. Ho and S. Odagiri, Agric. Biol. Chem., 42, 1063 (1978).

16) C. V. Morr, R. V. Josephson, R. Jenness and P. B. Manning, J. Dairy Sci., 54, 1555 (1971).

17) L. K. Creamer and S. Yamashita, New Zealand J. Dairy Sci. Technol., 11, 257 (1976).

18) C. W. Slattery, J. Dairy Res., 46, 253 (1979).

19) W. L. Choate, F. A. Heckman and T. F. Ford, J. Dairy Sci., 42, 761 (1959).

20) C. W. Slattery and R. Evard, Biochim. Biophys. Acta, 317, 529 (1973).

21) T. Ono, S. Odagiri and T. Takagi, Abstracts of Papers, 56th Meeting of Agricultural Chemical Society of Japan, April, 1981, p. 348. 